\title{
紫外線吸収方式簡易形 $\mathrm{NO}_{2}$ 計の試作
}

\author{
A simplified $\mathrm{NO}_{2}$ gas meter by the ultraviolet absorption method
}

南任 靖 雄 ${ }^{*}$

\section{Abstract}

A simplified $\mathrm{NO}_{2}$ (or $\mathrm{SO}_{2}$ ) gas meter at the emission sources of air pollutants was developed by the ultraviolet absorption method It is based on such principle that the ultraviolet rays are absorbed by $\mathrm{NO}_{2}$ or $\mathrm{SO}_{2}$ gases and the relation between the gas concentration and the transmission light quantity obeys Lambert-Beer's law. The system of the experimental apparatus consists of a halogen-lamp light source, photodiodes as the photoelectric transducers, the optical configuration of doublebeam and dual-wavelength, and the simplified analog IC data processing circuits. The prototype performance characteristics such as the detection characteristics and the measuring error were discussed theoretically and the experimental results were compared with the theoretical ones. The experimental results show that the sensitivity is $5 \mathrm{ppm} \cdot \mathrm{m}$ and the measuring error is \pm 2 percent in the range from 20 to 2000 ppm. The prototype instrument was found to be useful for the measurement of air pollutants at the emission sources.

摘 要

大気污染がスの測定法は, 測定の迅速性, 自動計測などの必要性から, 最近で, 化学的方法から物理的電子工 学的方法へと移行している. 物理的方法のうち紫外線吸収法は水分の干涉がないことなどから注目されている. 従 来の紫外線吸収方式大気污染ガス測定装置は大型で高価なものが多い. 本研究では, 簡便な測定器を得る目的で, 紫外線吸仪原理を用い, 光源にハロゲンランプ, 光電変換素子にホトダイオードを用い, 複光束, 2 波長方式併用 により両者の特徵を生かし，ホトダイオード出力をアナログ I Cによる単純な信号処理回路で, Lambert-Beerの 法則にもとづいて演算，デジタル表示する簡単な $\mathrm{NO}_{2}$ 計を試作し，その設計法，ガス濃度検出特性，詿差などを実 験的に検討した。その結果，検出感度 $5 \mathrm{ppm} \cdot \mathrm{m}$ ，試料セル長を $10 \mathrm{~cm}$ とした場合，測定レンジ $20 〜 2000 \mathrm{ppm}$ において， 平均誤差土 $2 \%$ 程度の $\mathrm{NO}_{2}$ 計が得られた。これは大気污染がス発生源用として有効であると考えられる。

\section{1. まえがき}

環境污染のうち大気污染はほとんどが人為的に発生 した污染物質によるが，大気污染がスの主要なものは， 硫黄酸化物 $\left(\mathrm{SO}_{2}, \mathrm{SO}_{3}\right)$, 窒素酸化物 $\left(\mathrm{NO}, \mathrm{NO}_{2}\right)$, 一酸化炭素 $(\mathrm{CO})$, 炭化水素, 硫化水素 $\left(\mathrm{H}_{2} \mathrm{~S}\right)$ などで, *神奈川県工業試験所
各種工場からの排ガス, 自動車排気がス，暖房用ボイ ラの排がス，焼却炉などからの排がスがその主な発生 源である11。

大気污染ガスの測定法には, 化学的方法および物理 的電子工学的方法があり, 最近では次第に後者に移り つつある2).化学的測定法は，ある程度時間をかけて污 Yasuo Nantou Industrial Research Institute of Kanagawa Rrefecture. 
染物質を捕集し，濃度を積分して測定するもので，主 なものには電気伝導法, 比色法などがあり, 現在環境 濃度で実用化されているものには，化学的方法が多い。 これは0.1ppm以下の環境濃度の測定が可能であるが, 他のガスの妨害を受け，測定䛊差を生じること，1 回 の測定に 30 分〜 1 時間くらいの時間がかかるこ， 水 を使うため，捕集液の交換など煩雑である欠点を有す る。これらの欠点を解消するため, 物理的電子工学的 方法が求められてきた。従来の方法には，非分散形赤 外吸収法, ケミルミネッセンス法, 水素炎イオン化法, 炎光光度法, 相関分光法, 非分散形赤外相関分光法お よびレーザを用いる方法などがある。また最近の研究 例にはコンピュー夕を用いて信号処理を行ない，精度 をあげようと試みた例がいくつかある3 $3{ }^{4 h}$. 5). 一方，大 気污染がスのうち， $\mathrm{SO}_{x}, \mathrm{NO}_{x}$ などの測定法として紫 外線吸収方式が，水分の干涉がなく，自動計測に適し ているため, 脚光をあびている6.7188.

紫外線吸収方式は，J I S K0104，K0103，B7981 など窒素酸化物や硫黄酸化物の測定に採用されている.

これらのガスは，図ー1に示すように紫外域に特有 の吸収スペクトルを有している（NO：195〜230 nm, $\left.\mathrm{NO}_{2}: 350 \sim 450 \mathrm{~nm}, \mathrm{SO}_{2}: 250 \sim 310 \mathrm{~nm}\right)$. 排ガスでは, 一般に $\mathrm{NO}_{x}$ より $\mathrm{SO}_{x}$ の濃度が大であり, $\mathrm{N} O$ 測定に $\mathrm{SO}_{2}$ の干涉がみられ，それを避けるため，紫外吸収法 ではN Oを $\mathrm{NO}_{2}$ に変換することでNO $\mathrm{N}_{x}$ として測定する 方式が普及している。紫外吸収法では, $\mathrm{NO}, \mathrm{NO}_{2}$, $\mathrm{SO}_{2}$ の吸収位置を分光素子（フィルタや回折格子）に より固定して測定するいわゆる分散形が採用され, 従 来, 単光束, 複光束, 2 波長の三方式がある. 図-2 に各方式の光学系統図を示す．複光束方式は，七ルの 污れの影響もあり，ブランク補償対策が不十分である ので，低価格の単光束方式か，ブランク補償のよい 2 波長方式が一般に用いられている。この他に，2 波長 測光方式であるが, 煙道自体を直接測光セルとする直

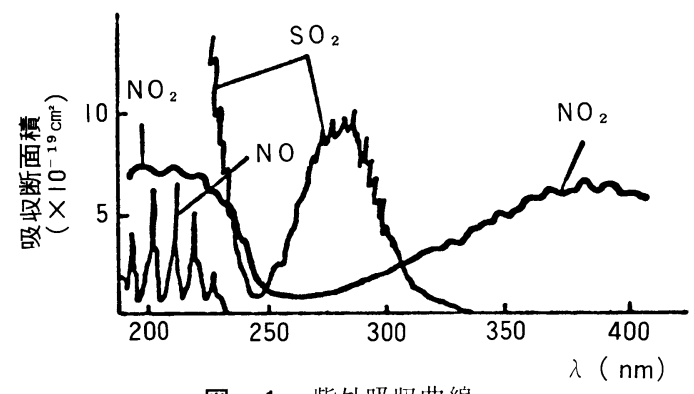

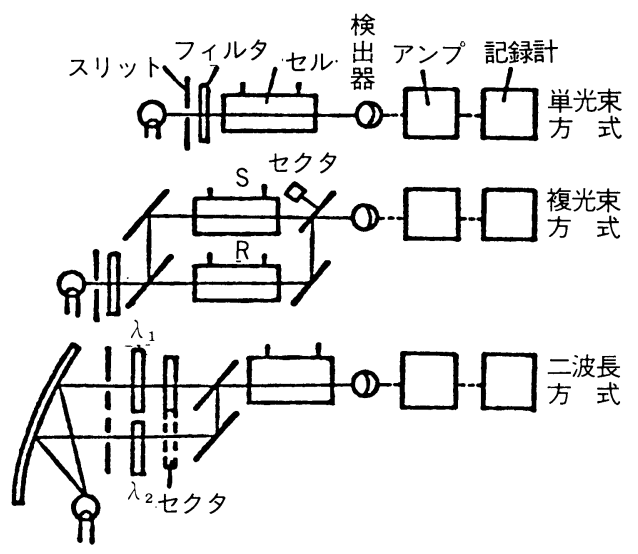

図ー2 紫外線吸仪 $j$ 式の種類

接導入形紫外吸収法 $\left(\mathrm{NO}, \mathrm{NO}_{2}, \mathrm{Sc}\right.$ 。および硫黄 化合物が炎中で $\mathrm{S}_{2}$ の分子発光を生じ, 癸劣搔度が $\mathrm{SO}_{2}$ 濃度の約 2 乗に比例するため, 波長 $394 \mathrm{~nm}$ の干涉フィ ルタを用いて $\mathrm{SO}_{2}$ や硫黄系悪臭成分を分析するのに利 用される炎光光度検出法 (F P D ) などがある.

本報告には，紫外線吸収方式のうち，複光束および 2 波長方式を併用し，試料セル㝕の污れの影響を少な くするなど，2方式の特徵を生かして，倍号処理演算 回路をアナログI C 在用いて簡単化した。大父活染が ス測定器を設計, 试作, その動作特性, ガス濃度特性, 測定䛊差など基本的な事項を実験検討し，設計データ を收集した。すなわち，光源としては八ロゲンランプ を使用，紫外域に感度を有するホトダイオードを光電 変換素子として用い, 試料がスの種類に応じて分光素 子（光学フィル夕）を切り換之, 検出電流を超低バイ アス電流オペアンプにより増幅,その出力をIC－LOG AMPに加え，Lambert-Beerの法則にもとづいて濃度 を算出し，A/D変換してデジタル表示する方式である。 以下にその概要を述べる。

\section{2. 測定原理}

紫外線吸収方式は，ガス状分子スペクトル特有の吸 収を利用するものである。寒験では $\mathrm{NO}_{2}$ ガス（吸収波 長350〜450 nm)について测定を行なった。NOガスにつ いては $\mathrm{NO}_{2}$ に変換してNOxとして測定されるのが通例 である。また $\mathrm{SO}_{2}$ ガスについては光源，光電変換素子， 分光素子の選択により測定可能である.

図ー3に試作装置の光学系統に関する原理図を示す。 $\mathrm{NO}_{2}$ ガスの吸収位置を分光素子 (光学フィル夕) で固 定して測定する分散形とし, 複光束方式と 2 波長方式 の両方式を併用する複光束 2 波長方式として試作し, 


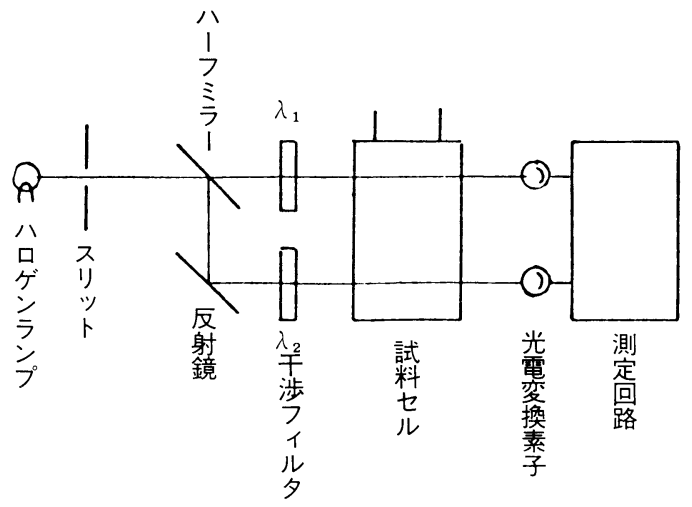

図-3 試作 $\mathrm{NO}_{2}$ 計光学系統困

試料セル空の污れによる影響をなくし，機械的光チョ ッパ機構は用いないなど簡素化した。光源にはハロゲ ンランプ $(12 \mathrm{~V}-6 \mathrm{~A})$ を採用, 光束はスリットを通 り，ハーフミラーで二分され，干渉フィルタ $\lambda_{1} ， \lambda_{2} に$ よって, $\mathrm{NO}_{2}$ ガスの最大吸収波長附近の $410 \mathrm{~nm}$ および 不感帯の $600 \mathrm{~nm}$ の波長の光に区分され, 七ル中の試料 ガスを通って紫外領域に感度を有するホトダイオード で検出される．600nmの波長の光は $\mathrm{NO}_{2}$ ガスによって 減衰をうけないが, $410 \mathrm{~nm}$ の波長の光は $\mathrm{NO}_{2}$ ガス濃度 に応じて吸収を受け，光度が減少する。

煙道排がスなどの試料がスをセル中に導入して，紫 外線吸収法により，ガス濃度を測定する場合，ガス濃 度 $(C)$ と入射光 $\mathrm{L} I(\lambda)$ および透過光 $\mathrm{L} T(\lambda)$ の関係
は, Lambert-Beerの法則により次式で与えられる。5)7/8)

$$
\alpha C l=\ln \left[L_{I}(\lambda) / L_{T}(\lambda)\right]
$$

ここで $\alpha$ : 定数, $l:$ 試料セルの長さ, $\lambda:$ 光の波 長,

したがって, ガス濃度 $(C)$ は, 試料セルの長さ $(l)$ を一定にすれば, 波長 $(\lambda)$ における入射光と透過光 の比を測定することによって(1)式から求められる。波 長 600nmにおいては， $\mathrm{NO}_{x} ， \mathrm{SO}_{x}$ などのガスによる吸 収は, $1000 \mathrm{ppm}$ 以下の低濃度ではほとんどゼロと考之 られ，入射光 $L_{I}(\lambda)$ を波長 $600 \mathrm{~nm}\left(\lambda_{2}\right)$ の干涉フィ ルタを通した光を検出することによって測定する。ま た，透過光 $L_{T}(\lambda)$ は，波長 $410 \mathrm{~nm}\left(\lambda_{1}\right)$ の干涉フィ ルタを透過した光により測定する。

\section{3. 測定回路および実験結果}

図ー4 に測定回路を示す。 $\mathrm{PD}_{1}, \mathrm{PD}_{2}$ は光電変換素 子で，同一規格の紫外域用ホトダイオードを用いた $(\mathrm{S}$ 社製 $9.0 \times 9.0 \mathrm{~mm}, \lambda=200 \sim 1100 \mathrm{~nm})$. ホトダイオー ド $\mathrm{PD}_{1}, \mathrm{PD}_{2}$ は照度一出力電流特性が直線的なものを 選べば，その出力電流は照度に比例すると考えてよい． ホトダイオード $\mathrm{PD}_{1}$ は，波長 $\lambda_{1}(410 \mathrm{~nm})$ の光を検出し， $\mathrm{NO}_{2}$ ガスによる光の吸収はホト夕゙イオードの出力電流 の減少となって表われる。また, ホトダイオード $\mathrm{PD}_{2}$ は波長 $\lambda_{2}(600 \mathrm{~nm})$ の光を検出し, 試料がスによる吸 收はほとんど行なわれないと考えられるので，ホト夕゙

$0.001 \mu$

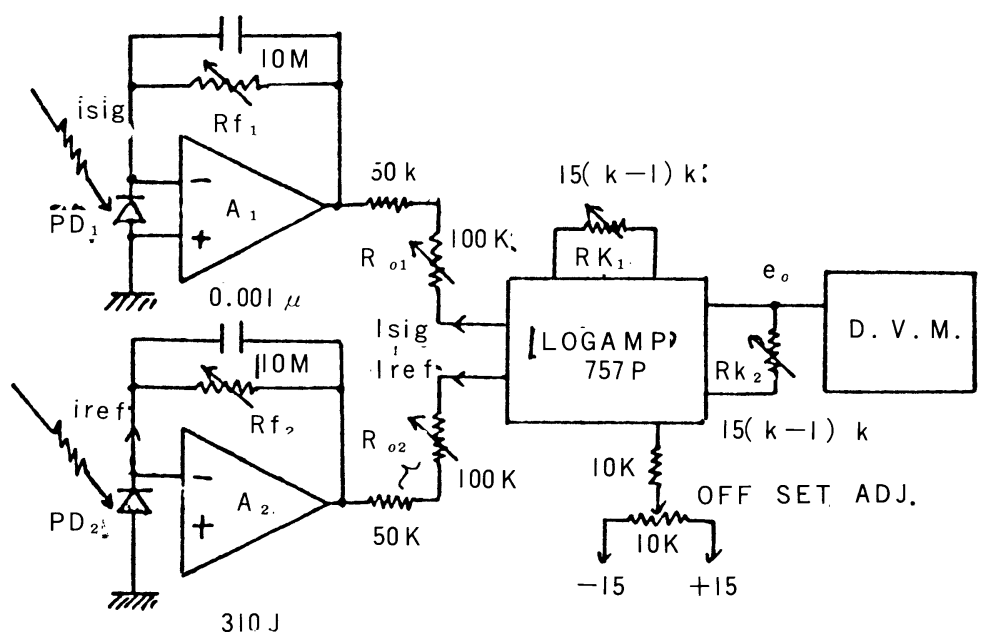

図-4 測定回路 
イオード $\mathrm{PD}_{2}$ の出力電流は入射光に比例した電流と考 えても差しつかえない.したがって入射光挹よび透過 光の比はこれら二つの電流比として計算できる. 図一 4 において, 超低バイアスオペアンプ $\mathrm{A}_{1}, \mathrm{~A}_{2}$ は電流 一電压変換器を構成し, その出力電压 $e_{A_{1}}$ および $e_{A_{2}}$ は それぞれ， $e_{A_{1}}=-i_{s i g} \cdot R_{f_{1}}, e_{A_{2}}=-i_{r e f} \cdot R_{f_{2}}$ で あるから, LOG A M P 入力電流 $I_{s i g}$ およびI refはそ れぞれ，

$$
\begin{aligned}
& I_{s i g}=e_{A_{1}} / R_{01}=-i_{s i g} \cdot\left(R_{f_{1}} / R_{01}\right) \\
& I_{r e f}=e_{A_{2}} / R_{02}=-i_{r e f} \cdot\left(R_{f_{2}} / R_{02}\right)
\end{aligned}
$$

となり， $I_{s i g}, I_{r e f}$ はそれぞれ透過光， 入射光に比例 した電流になる。オペアンプ $\mathrm{A}_{1}, \mathrm{~A}_{2}$ は超低バイアス入 力電流オペアンプ ( $\mathrm{A}$ 社製, 最大バイアス電流 $10^{-14} \mathrm{~A}$ ) であるので，入力の微弱な電流変化をも増幅できる。 電流 $I_{s i g}$, および $I_{r e f}$ は次のIC LOG AMPの入力端 子に印加され，(1)式が演算される。IC LOG AMP出 力 $\left(e_{0}\right)$ は, スケールファク夕 $(k)$ を用いて次式で 表わされる。すなわち、

$$
e_{0}=k \log _{10}\left(I_{\text {ref }} / I_{s i g}\right) \fallingdotseq 0.434 k \ln \left(I_{\text {ref }} / I_{\text {sig }}\right)
$$

一方, (1)式からガス濃度 (C) は

$$
C=\frac{1}{k^{\prime}} \ln \left(I_{r e f} / I_{s i g}\right)
$$

ここで $k^{\prime}=\alpha \cdot l=$ const.

(4)，(5)式からガス濃度 C は次式のようになる.

$$
C=\left(\frac{1}{0.434 k}\right) \cdot\left(\frac{1}{k^{\prime}}\right) e_{o}=F e_{0}
$$

ここで $\cdot F=\left(1 / 0.434 k k^{\prime}\right)$

したがって, ガス濃度 CはLOG AMP出力電圧 $\left(e_{0}\right)$ に比例し, スケールファクタ $(k)$ を既知のガス濃度 によって調整しておくことにより，D.V.M. で直読で き, デジタル表示される。

回路の調整は, 濃度既知の標準ガスを試料セル中に 導入して行ない, 図ー4において, ガス濃度 0 ( のとき, $I_{s i g}=I_{r e f}$ となるようボリューム $R_{01}, R_{02}$ を 調整する。次に標準がス濃度を測定レンジの最大值附 近にして, 最大目盛値となるようボリューム $R_{k 1}, R_{k 2}$ を調整することによりスケールファクタkを調整する. そのときのD.V.M.の読み（e。 ）が濃度 C $(\mathrm{ppm})$ にな

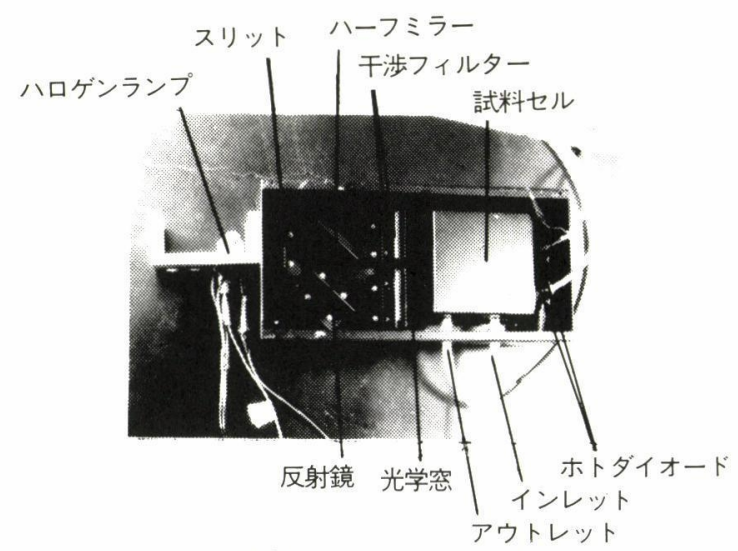

写真 1 検出部内部構造

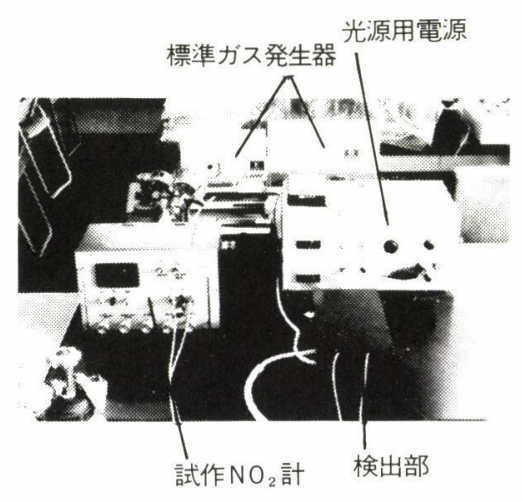

写真 2 実験装置

る.

次に試作装置の動作特性およびガス濃度特性などの 丰験結果について述べる。写真 1 に試作装置のガス導 入セルおよび光学系統から成る検出部内部構造を, 写 真 2 に実験装置を示す。一般にハロゲン電球は, 可視 域から紫外域までほぼ等しい分光分布をもっていると いわれている9). $\mathrm{NO}_{2}$ ガスの光吸収は，350－450nm $\left(\mathrm{SO}_{2}\right.$ では250〜310nm) 附近にあり，光源としてハロ ゲン電球（D C $12 \mathrm{~V}-6 \mathrm{~A}$ ) を用いた. 分光素子には, 光学フィルタ (干涉フィル夕, 中心波長, $410 \mathrm{~nm}$ およ び $600 \mathrm{~nm}$, 半值幅 $18 \mathrm{~m} \mu$ ，および $15 \mathrm{~m} \mu$ 以下)を使用した。 光電変換素子はホトダイオード（素子寸法 $9.0 \times 9.0 \mathrm{~mm}$, 波長入 200 ～1100nm）を用いた。

図ー 5 にホトダイオードの照度一出力電流特性の実 測例を示す。照度対出力電流特性は照度20ルックス以 上で直線性を有している。

入射光を波長 $\lambda_{2}(600 \mathrm{~nm})$ の光電変換出力すなわち レファレンス入力 $\left(I_{r e f}\right)$ とした場合の影響を調べる ため, 試料セルに標準ガス発生器から各種濃度の $\mathrm{NO}_{2}$ 


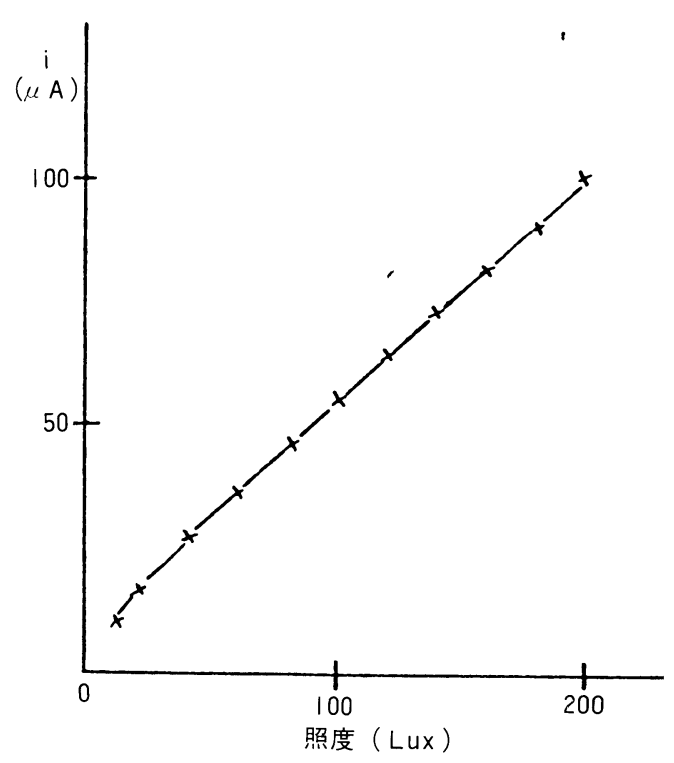

目ー5 ホトダイオード特性

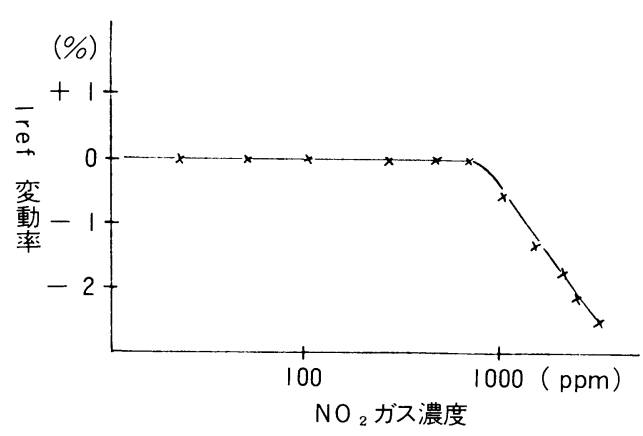

図ー6レファレンス電流変動率

ガスを導入し，ガス濃度に対するレファレンス入力 $\left(I_{r e f}\right)$ の変動率を测定した結果を図ー6に示す。グ ラフからがス濃度2000（ppm）でIref変動率は $2 \%$ 程 度となっており，1000（ppm）以下の濃度では変動は ほとんどゼロとみてよいことがわかる。したがってこ の程度のガス濃度测定においては，入射光照度がレフ アレンス入力 $\left(I_{r e f}\right)$ に比例するとしても差しつかえ ない。

次に, 試作装置の検出部のガス感度特性を調べるた め, 娭出部について, ガス濃度距離積と, $\tau(\lambda)=\ln$ $\left(i_{r e f} / i_{s i g}\right)$ の関係を测定した。すなわち, 試料セ ル長（l）は10cmであるので, 標準がス発生器から規 定のガス濃度のがスを試料セル中に導入 (バランスガ スは $\mathrm{N}_{2}$ 純がスを用いた)，ホトダイオード $\mathrm{PD}_{1}, \mathrm{PD}_{2}$ の 出力電流 $\left(i_{s i g}, i_{r e f}\right)$ を测定し, Lambert-Beer の

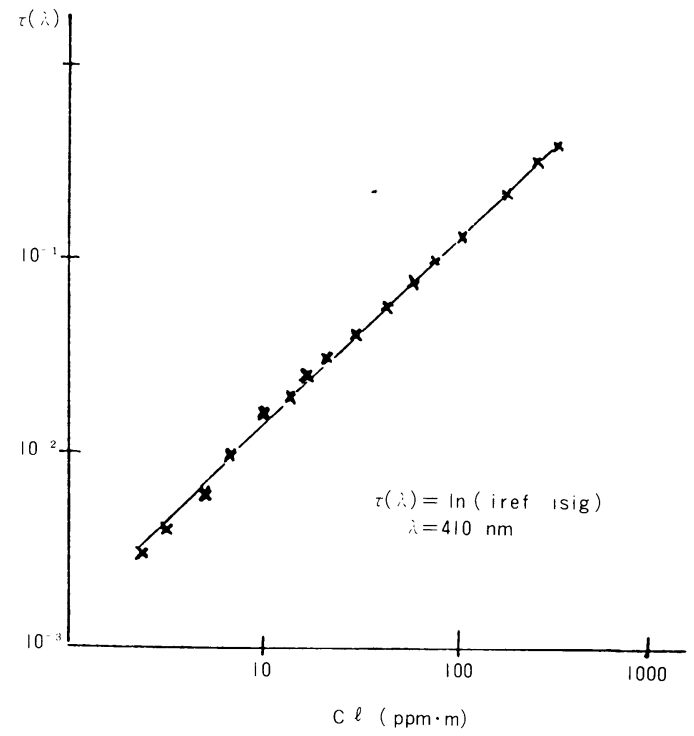

図ー 7 検知部がス感度特性

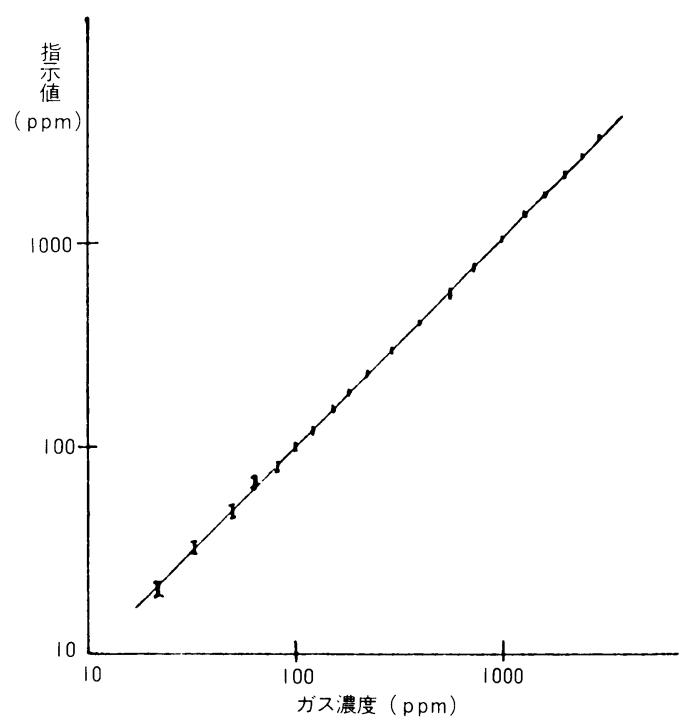

图ー8 測定例 $\left(\mathrm{NO}_{2}\right.$ ガス $)$

法則により，実際のガス濃度は $\tau(\lambda) に$ 比例するので, $\tau(\lambda)=\ln \left(i_{\text {ref }} / i_{\text {sig }}\right)$ を計算し, 横軸に濃度距離 積 $(C \cdot l)$ を, 縦軸にて $(\lambda)$ をとってグラフに表わし た。図ー7にその測定結果を示す。グラフから，がス 濃度距離積 $5 \mathrm{ppm} \cdot \mathrm{m}$ 以上ではほぼ直線性を有し，この

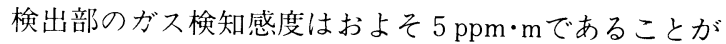
判る.

図ー8には, 試作 $\mathrm{NO}_{2}$ 計を用いて, 標準がス発生器 から各濃度の $\mathrm{NO}_{2}$ ガスを試料セル中に導入して測定し

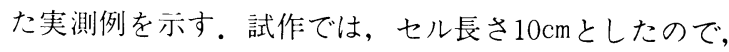


20ppm以下では誤差が大きくなっているが，5\%の許 容䛊差範囲では，50〜2000 ppmが测定可能であった。 図ー7の結果から推測されるように，七ル長を $1 \mathrm{~m} に$ すれば, 5 ppmの分解能で測定可能と思われる。

\section{4. 測定誤差および考察}

誤差要因としては，大きく分けて，(1)ホトダイオー ドの量子雑音, (2)光源出力変動, (3)光学系効䜌の変動, (4)電子信号処理系の内部雑音（負荷抵抗の熱雑音, A ／Dコンバー夕の量子化雑音など）が考之られ，精度 们上のためには，主として， $\mathrm{S} / \mathrm{N}$ 比良く光電変換を 行なう方法, 光源の出力口らぎの対策などが重要であ る。そこで光源の出力ゆらぎが，ガス濃度测定精度に 与之る影響について検討する。

今光源のゆらぎから生じる指小愦差を求めてみよう。 ガスの測定濃度は前述の(6)式でホされ，回路の調整に より，ガス濃度1000（ppm）のとき, LOG AMP出力 が1000 (mV)，すなわち，ガス濃度を $1 \mathrm{mV} / \mathrm{ppm}$ となる ように設定すると，(6)式は次式のようになる。

$$
C^{\prime}=1000 e_{o} \quad(\mathrm{ppm})
$$

(7)式において， $e_{o}$ は $\mathrm{m} V, C$ はpmの単位を有する。こ こで光源のゆらぎは入力電流の変動となって表われる ので, 入力電流の変動分を $\Delta$ とし, ガス濃度誤差 $\Delta C$ （ppm）を求めてみる。(5)式から

$$
\begin{aligned}
& C+\Delta C=\frac{1}{k^{\prime}} \ln \left(\frac{I_{\text {ref }}+\Delta I_{\text {ref }}}{I_{\text {sig }}+\Delta I_{s l g}}\right) \\
& =\frac{1}{k^{\prime}} \ln \left(\frac{I_{r e f}}{I_{s i g}}\right) \quad\left(\frac{1+\Delta I_{r e f} / I_{r e f}}{1+\Delta I_{s i g} / I_{s i g}}\right)=\frac{1}{k^{\prime}} \ln \left(\frac{I_{r e f}}{I_{s i g}}\right) \\
& +\frac{1}{k^{\prime}} \ln \left(\frac{1+x}{1+y}\right) \\
& \text { ここで } k^{\prime}=\alpha l=\mathrm{const}, \quad x=\Delta I_{r e f} / I_{r e f}, \\
& y=\Delta I_{s i g} / I_{s i g} \text { である. }
\end{aligned}
$$

(8)式にテーラー展開を用いて書き変えると，ガス濃度 鿁差は次式のようになる。

$$
\begin{aligned}
\Delta C= & \frac{1}{k^{\prime}} \ln \left(\frac{1+x}{1+y}\right)=\frac{1}{k^{\prime}}\left(x-\frac{x^{2}}{2}+\frac{x^{3}}{3}-\frac{x^{4}}{4}+\cdots \cdots\right) \\
& -\frac{1}{k^{\prime}}\left(y-\frac{y^{2}}{2}+\frac{y^{3}}{3}-\frac{y^{4}}{4}+\cdots \cdots \cdots\right) \\
= & \frac{1}{k^{\prime}}\left\{(x-y)-\left(\frac{x^{2}-y^{2}}{2}\right)+\left(\frac{x^{3}-y^{3}}{3}\right)-\right. \\
& \left(\frac{x^{4}-y^{4}}{4}\right)+\cdots \cdots \cdots \cdot \ldots \cdots \cdots \cdots \cdots \cdots \cdots(9)
\end{aligned}
$$

ここで $x \ll 1 ， y \ll 1$ であるから，(9)式の 2 乗以上： の項を省略すると,

$$
\Delta C \doteqdot \frac{1}{k^{\prime}}(x-y)=\frac{1}{\alpha l}\left\{\frac{\Delta I_{r e f}}{I_{r e f}}-\frac{\Delta I_{s i g}}{I_{s i g}}\right\} \cdots \cdots \cdots(10)
$$

となる。

一方実験装置を用いて䇥数 $k^{\prime}$ を求めるため, 標準が ス発生器により, 各種濃度の $\mathrm{NO}_{2}$ ガスを試料セル中に 導入し, 各がス濃度に対する $\ln \left(I_{r e f} / I_{s l g}\right)$ を求め た。その結果から定数 $k^{\prime} の$ 平均值は $1.69 \times 10^{-4} / \mathrm{ppm}$ になった（6)式に定数 $k^{\prime}\left(1.69 \times 10^{-4} / \mathrm{ppm}\right)$ を代入 し，また，(7)式から定数 $F=1000$ であるから，スケー ルファクタ $(k)$ の值は約13.7になる。(10)式にk'の值 $1.69 \times 10^{-4} / \mathrm{ppm}$ を代入すると光源の叻らぎによる䛊 差は次式になる。

$$
\begin{aligned}
& \Delta C \doteqdot \frac{1}{k^{\prime}}\left\{\Delta I_{r e f} / I_{r e f}-\Delta I_{s l g} / I_{s l g}\right\} \\
& =\left\{\Delta I_{r e f} / I_{r e f}-\Delta I_{s l g} / I_{s l g}\right\} \times 5.93 \times 10^{3}(\mathrm{ppm})
\end{aligned}
$$

上:式から，光源のゆらぎによる誤差はホトダイオー ドの忡力電流変動率の差に比例することになる。標淮 ガス発生器により, 試料セルに導入するガス濃度を特 定の值 $(100 ， 500 ， 1000 \mathrm{ppm}$ の 3 点) とし，光源の供 給電圧を可変して，ホトダイオードの出力電流を変化 し， $\Delta I_{r e f} / I_{r e f}, \Delta I_{s \imath \mathrm{g}} / I_{s \imath \mathrm{g}}$ のそれぞれの储に刘する ガス濃度誤差を奉测した結果，上の(11)式による計算結 果と良く一致した。

図ー9は光源の供給電源に定電圧電源（リップル； $2 \mathrm{mV} r \mathrm{~ms}$ 以下, 出力安定度; 電源電压 $\pm 10 \%$ に対し,

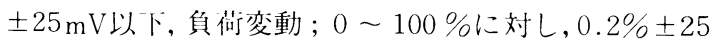
$\mathrm{mVW}$ 以下)を使用し、システム総合の指示䛊差を测定し た結果を亦す。ガス濃度 $20 \mathrm{ppm}$ 2000ppmでは䛊差最 大土 $4 \%$ ，平圴士 $2 \%$ 程度であった。

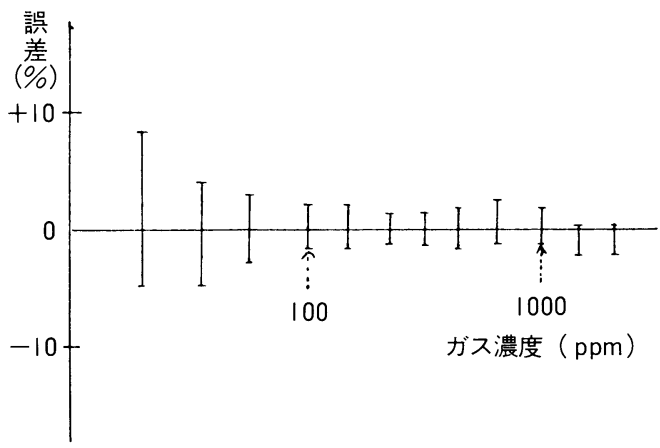

図ー9システム総合测定誤差 


\section{5. むすび}

複光束 2 波長併用方式の光学系で構成される検出部 を有し，光源にハロゲンランプを用い，紫外域に検出 感度を有するホトダイオードで光電変換し，超低バス アスI Cによる信号処理を行なった，簡易形の柴外吸 収方式 $\mathrm{NO}_{2}$ 計を試作し，その設計法，がス濃度検出特 性，测定䛊差などについて述べたが，要約すると，以 下のとおりである。

(1)この程度の処理回路による簡単な方式でも， $\mathrm{NO}_{2}$ ガ 又濃度 $5 \mathrm{ppm}$ 程度の分解能をもつものが憋作可能で ある。

(2)試作装置は, 测定光学空の污れなどの影響をうけず 大気污染がス発生源用として有効であると考えられ る.

(3)测定䛊差は，光源のゆらぎによるものが大きいと考 えられるので, 光源の供給電源は安定化する必要が ある。

(4)さらに测定感度をあげるため, 柴外域において光強 度の大きい安定な光源招よび光電変換効率の上い光 電変換素子についての検討が必要である。

(5)測定精度をあげるためのシステム的な検討は，光学 系統を多チャンネルにするなど検出部光学系の検討 およびマイクロコンピュー夕による適切な信号処理 の方法などを考慮する必要がある。

(6) $\mathrm{SO}_{2}$ ガスについても，フィルターなど光学素子の変 更により，同様に测定可能と获えられるが，最適化 のための今後の実験的検討が必要である.

\section{引用文献}

1 ) 岡正太郎, 田中正男：環境システムにおける計測法, 電気 学会誌, Vol.95, No.11, p. 982 989(昭50-11)

2 ) 五十嵐隆：大気污染の検出, 電子通信学会誌, Vol. 56, No. 5, p. 651 656(1973-5)

3 ) J. Johansson他: Computer Automation and Error Analysis of a $\mathrm{CO}_{2}$-Laser Long-path Absorption System for Air pollution Monitoring, IEEE Trans. Instrum. Meas., Vol. IM -27, No. 4, p. 358 -363, D ec. 1978.

4 ) D. Onderdelinden, L. Strackee : Conputer Assisted Correlation Spectrometer for the Remote Sensing of Air Pollution, Rev. Sci. Instrum., Vol. 48, No.7, p. 752 756, July 1977 .

5 ）佐野, 古賀他：パルス動作可同調レーザによる大気污染測 定システム, 電子通信学会論文誌, Vol. J61-C, No.11, p. $743 \sim 744(1978-11)$

6 ) 酒井馨: 大気污染の自動計測，日本化学会関東支部講習会 テキスト, p. 1 23 (昭53-3)
7 ) 近藤凱昭：新しい紫外線吸収方式の排がス自動計測器, 電 子計测, Vol. 14, No.10, p. 17 22 (昭49-10)

8 ) 菊池誠：煙道がス測定器とその適用, 計測技術, Vol. 4 , №. 7, p. $62 \sim 71$ (昭51-7)

9 ) 吉永弘: 応用分光学ハンドブック, p. 228 , 朝倉書店 (昭48)

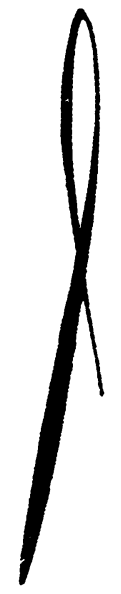

